\title{
THE INFLUENCE OF SURFACES MODIFIED BY DIFFERENT POLYMERIC SUBSTANCES ON THE GROWTH OF MOUSE EMBRYONIC FIBROBLASTS CELL LINE NIH3T3
}

\author{
O. Shtapenko \\ shtapenko31@gmail.com
}

\author{
Institute of Animal Biology NAAS,
}

38 Stusa str., Lviv 79034, Ukraine

Cultivating cells on synthetic surfaces has ensured the most approximated to in vivo conditions, cell growth, migration, differentiation, synthesis of the extracellular matrix components. Cell proliferation and viability are affected by surface chemical and phase composition, surface conformation, surface morphology and specific chemical groups on the surface of the scaffold. In our study, we investigated the effects of modified nanosurfaces, a grafted by polymeric of dextran, APTES and albumin on the proliferation and metabilitic activity of the cells-fibroblasts of NIH3T3 line.

For experiments, NIH3T3 cell line was cultured in medium RPMI 1640 with $10 \%$ FCS, $1 \%$ penicillinstreptomycin in $5 \% \mathrm{CO}_{2}$ at $37^{\circ} \mathrm{C}$ for 72 hours. Cells were seeded at the glass plates, which modified nanolayers in various combinations: Glass/APTES, Glass/APTES/dextran, Glass/APTES/albumin, Glass/albumin, Glass/APTES/dextran/albumin; control group - clean glass. During the study the intensity of proliferative growth of NIH3T3 cell line and its viability to form a monolayer was determined by Trypan blue staining after every 24 h of incubation. For investigation of the metabolic cell parameters (lactate dehydrogenase (LDH) activity, glucose concentration culture medium was collected after 24, 48 and 72 hours of cultivation.

The result indicate that surfaces modified by albumin, APTES/albumin and APTES/dextran/albumin showed a higher proliferative effect on NIH3T3 cell line compared to the surface "native glass" (control group) at 24 hours of cultivation. Surfaces enclosing APTES and mixed APTES/dextran assume a higher viability and metabolic activity of the culture in terms of the activity of $L D H$ and glucose concentration at 48 hours of cultivation. After 72 hours of cultivation, the intensity of cell proliferative growth was seen only in APTES/dextran surface, while in other research groups cells concentration was at the level of the control group.

Obtained results have shown that the glass surface modified with grafted nanolayers of APTES, dextran and albumin is nontoxic and can be used for cultivation of cells.

Keywords: CELL CULTURE, PROLIFERATIVE ACTIVITY, SURFACE, NANOLAYERS, APTES, DEXTRAN, ALBUMIN, CYTOTOXICITY

\section{ВПЛИВ ПОВЕРХОНЬ, МОДИФІКОВАНИХ РІЗНИМИ ПОЛІМЕРАМИ, НА РІСТ КЛІТИН ФІБРОБЛАСТІВ МИШІ ЛІНІЇ NІНЗТ3}

\author{
О. Штапенко \\ shtapenko31@gmail.com
}

Інститут біології тварин НААН, вул. В.Стуса,

38, м. Львів, 79034, Україна

Культивування культур клітин на синтетичних поверхнях дозволяє забезпечити оптимально наближені до умов іп vivo, сприяс росту клітин, їх міграиії, диференціачії та формуванню міжклітинного матриксу. Хімічний та фазовий склад поверхонь, їх морфологія, конформачія прищеплених макромолекул на поверхні - ие головні фактори, які регулюють ріст клітин на поверхні і їхні функиї̈. Метою наших досліджень було вивчення впливу наноповерхонь, модифікованих полімерами APTES, декстран та альбумін, на проліферативну та метаболічну активність клітин фібробластів лінії NIH3T3.

У дослідженні використовували клітини лінії NIH3T3, які культивували на пожсивному середовищі RPMI 1640 з додаванням $10 \%$ ETC, 1 \% пеніциліну та стрептоміџину в атмосфері з вмістом $5 \% \mathrm{CO}_{2}$ за $37^{\circ} \mathrm{C}$ впродовж 72 годин. Клітини висівали на скельия, модифіковані нанотарами у різних комбінащіях: скло/APTES; скло/APTES/декстран; скло/APTES/альбумін; скло/альбумін; скло/APTES/декстран/альбумін; контрольна група - чисте скло.

Проліферативний ріст та життєздатність культури клітин NIH3T3 оцінювали підрахунком кількості клітин кожні 24 години. Для вивчення метаболічних параметрів клітин відбирали кондиційне 
середовище через 24, 48 та 72 години культивування для визначення активності лактатдегідрогенази (ЛДГ) і кониентрації глюкози.

Порівняно з поверхнею скла (контрольна група), на 24-у годину культивування спостерігалось значне зростання проліферації клітин на поверхнях, модифікованих альбуміном, АPTES/альбуміном та APTES/декстран/альбуміном, тоді як на 48-у годину культивування на нанопокриттях з APTES та APTES/декстраном сприяє найвищій життездатності і метаболічній активності культури клітин за показниками ЛДГ та рівнем глюкози. Висока інтенсивність проліферативного росту на 72-у годину спостерігалась тільки за культивування на поверхні APTES/декстрин, тоді як в інших досліджуваних групах кількість клітин була на рівні контрольної групи.

Отримані результати показали, щуо досліджувані наноповерхні, модифіковані АРТЕS, декстраном та альбуміном, є нетоксичними і можуть бути використані для культивування клітин.

Ключові слова: КУЛЬТУРА КЛІТИН, ПРОЛІФЕРАЦІЯ, ПОКРИТТЯ, АРТЕS, НАНОПОВЕРХНІ, ДЕКСТРАН, АЛЬБУМІН, ЦИТОТОКСИЧНІСТЬ

\title{
ВПЛИЯНИЕ ПОКРЫТИЙ, МОДИФИЦИРОВАННЫХ РАЗЛИЧНЫМИ ПОЛИМЕРАМИ, НА РОСТ КЛЕТОК ФИБРОБЛАСТА МЫШЕЙ ЛИНИИ NІНЗТЗ
}

\author{
O. Штапенко \\ shtapenko31@gmail.com
}

Институт биологии животных НААН,

ул. В.Стуса, 38, г. Львов, 79034, Украина

Культивирования культур клеток на синтетических поверхностях позволяет обеспечить условия оптимальные к іn vivo, что способствует росту клеток, их миграции, дифференциации и формированию междуклеточного матрикса. Химический и фазовый состав поверхностей, их морфология, конформация макромолекул являются главными факторами, которые регулируют рост клеток на поверхности и их функиии. Целью наших исследований было изучение влияния наноповерхностей, модифицированньх полимерами APTES, декстран и альбумин, на пролиферативную и метаболическую активность клеток фибробластов линии NIH3T3.

Для исследований использовали клетки линии NIH3T3, которые культивировали в питательной среде RPMI 1640 з добавлением $10 \%$ ЭСТ, 1 \% пенициллина и стрептомицина в атмосфере с содержанием $5 \%$ $\mathrm{CO}_{2}$ при $37^{\circ} \mathrm{C}$ в течение 72 часов. Клетки высевали на стекла, модифицированные нанослоями в различных комбинациях: стекло/APTES; Стекло/APTES/декстран; стекло/АPTES/альбумин; стекло/альбумин; стекло/APTES/декстран/альбумин; контрольная группа - чистое стекло. Пролиферативный рост и жизнеспособность культуры клеток NIH3T3 оценивали подсчетом количества клеток каждые 24 часа путем подсчета количества клеток после окраски трипановым синим. Для изучения метаболической активности клеток отбирали кондиционную среду через 24, 48 и 72 часа культивирования для определения активности лактатдегидрогеназы (ЛДГ) и концеентрации глюкозы.

При сравнении с поверхностью чистого стекла (контрольная группа) наблюдался значительный пролиферативный рост клеток на поверхностях, модифицированных альбумином, АРТЕS/альбумином и APTES/декстран/альбумином на 24 часа культивирования. Культивирование на нанопокрытиях с APTES и APTES/декстраном в течении 48 часов способствует высокой жизнеспособности и метаболической активности культуры клеток по показателям ЛДГ и уровню глюкозы. Высокая интенсивность пролиферативного роста на 72 часа наблюдалась только при культивировании на поверхности APTES/декстрин, тогда как в других исследуемых группах количество клеток была на уровне контрольной группь.

Полученные результаты указывают на отсутствие токсичности нанопокрытий, модифицированных APTES, декстраном альбумином, следовательно, эти покрытия могут быть использованы для культивирования клеток.

\section{Ключевые слова: КУЛЬТУРА КЛЕТОК, ПРОЛИФЕРАЦИЯ, ПОКРЫТИЯ, АРТЕS, НАНО- ПОВЕРХНОСТИ, ДЕКСТРАН, АЛЬБУМИН, ЦИТОТОКСИЧНОСТЬ}

Cell-based assays are an important element of the cytotoxicity discovery process the cellular responses to compounds and to avoid cost-inten- sive animal testing. To date, the majority of cellbased assays use two-dimensional (2D) monolayer cells cultured on flat substrates. But the cells in the 
in vivo environment are surrounded by other cells and extracellular matrix (ECM) in a three-dimensional (3D) fashion, 2D cell culture does not take into account the natural environment of cells [2]. Therefore, it is to develop in vitro cell-based systems that can more realistically show the in vivo cell behaviors and provide more predictable results to in vivo tests.

Cell adhesion is depended by surface hydrophilicity, surface charge density, surface morphology, specific chemical groups present on the surface of the scaffold [3]. Nanolayers surface properties regulate cell growth, migration, differentiation, synthesis of the extracellular matrix components [7, 14]. Given that surface chemistry is crucial for the biocompatibility of the nanolayers, specific surface modifications are used with different polymers $[8,12]$.

In particular, there is an increased interest in the polymeric surfaces which can change their affinity towards proteins and cells under external stimuli $[1,9]$ and therefore have potential applications in biology and medicine. From conditions to the surface modification for direct cellular adhesion and growth are chemical surface modification $[4,10]$, topographical surface modifications [5].

Despite various investigations, specific and complex mechanisms govern the reactions that occur between the biomaterial and the cellular environment are still incomplete understanding.

Cultivation of cell cultures on synthetic surfaces ensures optimum to in vivo conditions and all further processes of differentiation, proliferation and formation of extracellular matrix [6]. In previous works [13] it was shown that in terms of bioengineering is surface modified amino-contained substances, polysaccharides and proteins. But methods of investigations of effects of the biocompatible and smart bioactive surfaces on cells are still not fully developed. For these studies cell viability tests with counted a quantity of the living cells and also their proliferation index are usually applied.

\section{Material and methods}

Preparation of surface-modified glasses. Glass plates were dipped into $0.2 \%(\mathrm{w} / \mathrm{w})$ methanolic solution of (3-aminopropyl)triethoxysilane (APTES) for $24 \mathrm{~h}$. After the incubation, loosely- attached silane molecules were removed with methanol in Soxhlet's apparatus. With participation of these aminogroups dialdehydedextran obtained by partial oxidation of the anhydroglucopyranoside subunits of dextran by periodate acid was covalently grafted to the surface of the modified glass plates. The oxidation of dextran was conducted during $2 \mathrm{~h}$, and then the plates functionalized with amino-terminated APTES were dipped into $2 \%$ solution of dialdehydedextran in water for a grafting time of $6 \mathrm{~h}$. Similarly, loosely-attached dialdehydedextran was removed with water in Soxhlet's apparatus during $4 \mathrm{~h}$. As a result dialdehydedextran grafted to aminated surfaces were obtained.

After modification procedure all groups of samples were dipped in bovine serum albumin (BSA) phosphate-citric buffer solution $(\mathrm{pH}=7,4$; BSA $-0.2 \mathrm{mg} / \mathrm{ml}$ and adsorption time $-2 \mathrm{~h}$ ). $\mathrm{Ob}-$ tained surfaces were characterized by Ohar M. [11]. For simplification of the presentation, every type of the samples was arbitrary notated as number of the study group (SG).

Cell and culture conditions. Cell culture media and supplement were purchased from Sigma (USA); all other chemicals and reagents were purchased from GIBCO-BRL (Gaithersburg, $\mathrm{MD}$ ) and Fluka (Germany). For experiments, the NIH 3T3 mouse embryonic fibroblast cells (ATCC® CRL-1658) was used. The NIH 3T3 cells were cultured in RPMI 1640 culture medium with $10 \%$ fetal calf serum (FBS) and $100 \mathrm{mg} / \mathrm{ml}$ penicillin-streptomycin $(\mathrm{P} / \mathrm{S})$ in a humidified atmosphere $5 \% \mathrm{CO}_{2}, 95 \%$ air at $37^{\circ} \mathrm{C}$ for 72 hours. Cells $\left(0.1 \times 10^{6}\right.$ cells $\left./ \mathrm{ml}\right)$ were seeded onto surfacemodified glasses in the following order:

Glass (control);

Glass/APTES;

Glass/APTES/dextran;

Glass/APTES/albumin;

Glass/albumin;

Glass/APTES/dextran/albumin.

Cell proliferation evaluation. The viability of cells was determined by the Trypan blue staining method. Cells were selected every 24 hours. The cells were washed with phosphate-buffered saline and stained with Trypan blue (final concentration of the dye $0.4 \%$ ). Number of living (unfilled) and dead (filled) cells were counted in the Goryaev camera using light microscope. For investigation of 
the metabolic cell parameters (lactate dehydrogenase activity, glucose content) culture medium was collected after 24, 48 and 72 hours of cultivation.

Lactate dehydrohenase (LDH) assay. Medium supernatants collected from both experimental and control cells every $24 \mathrm{~h}$ were tested for LDH activity using Cytotoxicity Detection kit $L D H$ (Roche). This test is a colorimetric assay for the quantification of cell death and cell lysis based on the measurement of LDH activity released from the cytosol of damaged cells into the supernatant. The amount of enzyme activity detected in the culture supernatant correlates with the proportion of lysed cells. The assays were conducted following the manufacturer's instructions, in flatbottomed wells of 96-well plates. Following incubation, the absorbance of samples was measured using an ELISA plate.

Evaluation of cytotoxicity using the MTT assay. The MTT assay was used to assess the in vitro cytotoxicity of surface-modified glasses in this study. A quantitative colorimetric MTT test was performed after 3 days of culture to characterize cellular metabolism (vitality) and, by implication, proliferation. The MTT solution $(0.5 \mathrm{mg} / \mathrm{ml})$ was added to each well $3 \mathrm{~h}$ prior to the end of the experiment. After the incubation period in the dish was added dimethylsulfoxide to dissolve the purple formazan crystals that formed as a result of the restoration of MTT reagent-reductase living cells. The concentration of formazan in the wells was determined by spectrophotometric method for device "Plate Reader BioTek" (USA) by optical absorbance at a wavelength of $490 \mathrm{~nm}$. Number of living cells (in percentage) was determined by the ratio of optical in which the cells were incubated for study and control mediums.
Glucose uptake assay. Glucose levels in conditioned media were determined at 24,48 , and 72 hours after cultivation oviduct cells using a glucose assay kit (Roche) by spectrophotometrically measuring the absorbance at $630 \mathrm{~nm}$.

Statistical analysis. Tests were repeated three times for every type of the samples. The results were presented as mean \pm standard deviation. Differences between groups were determined by Student $t$-tests.

\section{Results and discussion}

The influence of the surface nature on the proliferative growth of NIH3T3 cells was investigated. Table demonstrates the growth of NIH3T3 cells on different nanolayers during 72 hours of cultivation.

The results of our investigate show that proliferative activity of NIH3T3 cells were significantly higher in experimental groups with APTES/albumin $(\mathrm{P}<0.05)$, albumin $(\mathrm{P}<0.001)$ and APTES/dextran/albumin $(\mathrm{P}<0.001)$ at 24 hour and were similar at 48 and 72 hours compared to controls. Improved viability and proliferation of the NIH3T3 cells was observed after cultivation on APTES and APTES/dextran nanolayers during 48 and $72 \mathrm{~h}$ compared to control and other experimental groups. Since cells proliferation responds to the surfaces, it could be concluded that the stereochemistry of the polymers used for preparation of surface-modified glasses greatly influences the cell growth and survival.

To confirm the viability and functional activity of embryonic fibroblasts cells under cultivation on different nanolayers we investigated of LDH levels. Thus, samples were collected from

Proliferative growth of NIH3T3 cells on the modified surfaces during $72 \mathrm{~h}$ of cultivation $(\mathrm{M} \pm \mathrm{SD}, \mathrm{n}=3)$

\begin{tabular}{|l|c|c|c|}
\hline \multirow{2}{*}{ Experimentals groups } & \multicolumn{3}{c|}{ The cells concentration after culturing, $\mathrm{ml}^{\mathrm{s}} \mathrm{sm}^{3}$} \\
\cline { 2 - 4 } & 24 hours & 48 hours & 72 hours \\
\hline Control (glass) & $1.27 \pm 0.01$ & $1.80 \pm 0.03$ & $1.81 \pm 0.07$ \\
\hline Glass / APTES & $1.33 \pm 0.15$ & $2.65 \pm 0.09^{* * *}$ & $2.15 \pm 0.03$ \\
\hline Glass / APTES / dextran & $1.27 \pm 0.03$ & $2.89 \pm 0.06^{* * *}$ & $2.53 \pm 0.02^{* * *}$ \\
\hline Glass / APTES / albumin & $1.46 \pm 0.01 * * *$ & $2.19 \pm 0.06^{* * *}$ & $1.85 \pm 0.05$ \\
\hline Glass / albumin & $1.71 \pm 0.01^{* * *}$ & $1.85 \pm 0.02$ & $1.85 \pm 0.08$ \\
\hline Glass / APTES / dextran / albumin & $2.0 \pm 0.03^{* * *}$ & $1.89 \pm 0.07$ & $1.80 \pm 0.04$ \\
\hline
\end{tabular}

Note: * $-\mathrm{P}<0.05 ; * *-\mathrm{P}<0.01 ; * * *-\mathrm{P}<0.001$ compared to the control. 
the medium of all experimental groups and control cultures at various time intervals. LDH activity in all groups was approximately the same as at the beginning of the experiment (fig. 1).

From with the increasing of cultivation time, LDH activity was changed differently for each group. The concentrations of LDH decreased significantly in experimental groups with APTES/albumin $(\mathrm{P}<0.01)$, albumin $(\mathrm{P}<0.05)$ and APTES/dextran/albumin ( $<<0.001)$. As opposed, in group with APTES the level of LDH was significantly higher $(\mathrm{P}<0.05)$ at 48 hour, compared to the control. Low lactate dehydrogenase activity was observed in the control group and all experimental groups at $72 \mathrm{~h}$ of cultivation, which coincides with the growth of the proliferative activity of cells in these groups and high cell viability.

Evaluation of glucose uptake is crucial in the study of cell viability and numerous metabolic disorders. A decrease in glucose concentration during the period of cultivation (fig. 2) was observed for control and all experimental groups.

However, the dynamics of change of glucose in the cultural medium was different for each experimental group. Thus, in group with APTES/ dextran/albumin the glucose contents was significantly lower $(\mathrm{P}<0.001)$ at $48 \mathrm{~h}$ and $72 \mathrm{~h}$ of cultivation compared to the control and other experimental groups that indicating the use of glucose as an energy substrate at an elevated level of biosynthetic processes in cells. At the same time, the glucose concentration was significantly higher in groups with APTES $(\mathrm{P}<0.05)$ and APTES in combination with albumin $(\mathrm{P}<0.01)$ than in control indicating about the low intensity of glucose consumption during incubation period. Our results showed that the nature of surface has regular influence on cellular metabolism.

Biocompatibility and functional impact of modified surfaces were studied in vitro using MTT assay. In fig. 3 the data of obtained results of MTT absorbance value for cells after cultivation onto different nanolayers are represented.

The cell viability in experimental group with APTES/dextran was the highest at $24 \mathrm{~h}$ but showed lower viability rate during cultivation from 48 to $72 \mathrm{~h}$ in comparison to other groups. The MTT assay showed $72-114 \%$ of viability to NIH3T3 cells exposed to all nanolayers eva- luated. The absorbance values in experimental groups with APTES/albumin and APTES/dextran/albumin increased to $93.1 \%$ and $97.1 \%$ at $72 \mathrm{~h}$ compared to other groups although cell viability in experimental group with APTES/ albumin was similar during $24-72 \mathrm{~h}$ of cultivation while in group with APTES/dextran/albumin decreased.

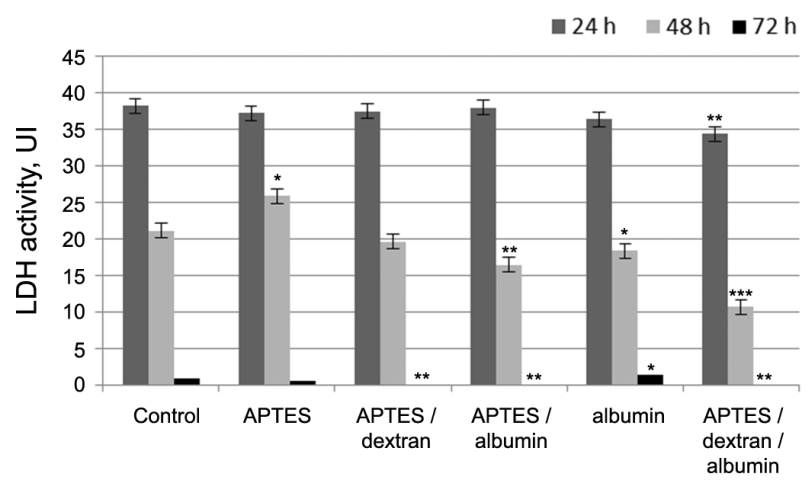

Fig. 1. LDH activity in culture medium after cultivation of NIH3T3 cells on different nanolayers during $72 \mathrm{~h}$ $(\mathrm{M} \pm \mathrm{SD}, \mathrm{n}=3)$

Note: here and further * $-\mathrm{P}<0.05 ; * *-\mathrm{P}<0.01$; $* * *$ _ $\mathrm{P}<0.001$ compared to the control.

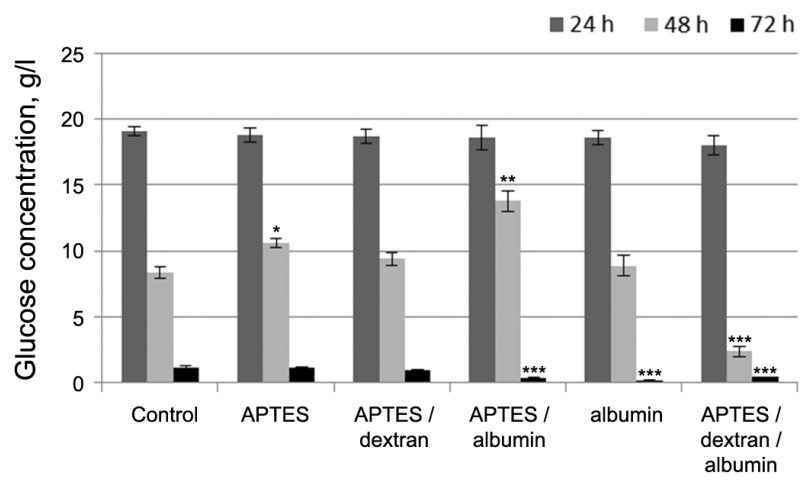

Fig. 2. Effect of different nanolayers on glucose concentration in conditioned medium of NIH3T3 cells after 72 hours of cultivation $(\mathrm{M} \pm \mathrm{SD})$.

The results indicate the standard deviation

from mean values derived from three replicates

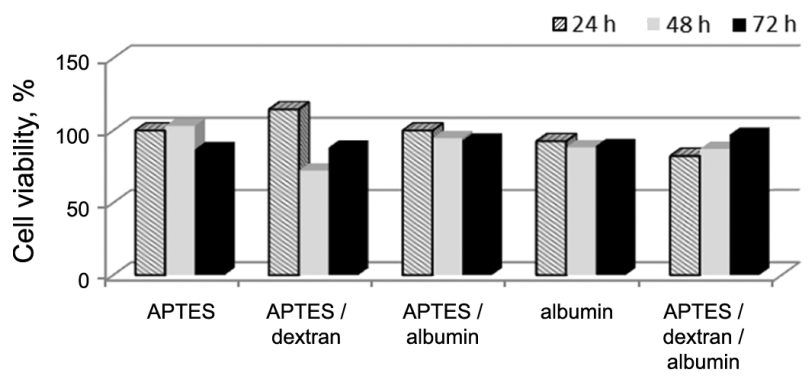

Fig. 3. Viability of NIH3T3 cells exposed on different nanolayers after $72 \mathrm{~h}$ incubation. The cytotoxicity was determined by MTT assay as the percentage of experimental cells compared with control 


\section{Conclusions}

The different nanostructured layers were created by grafting of APTES, dextran and albumin on glass surfaces. The effect of those nanolayers was studied in terms of change cell viability and morphology of NIH3T3 cell line under cultivation in vitro. The results showed that all glass surfaces modified with grafted nanolayers of APTES, dextran and albumin are nontoxic and can be used for cultivation of cells. It was found out that modification of the surface by APTES and APTES/dextran leads to improving the viability and proliferation of NIH3/T3 cell line.

Prospects for further research. Evaluation of the effect of nanolayers on the frequency of the apoptosis in NIH3T3 cell line culture using specific fluorescent staining dyes will be studied.

1. Brynda E., Houska M., Jirouskova M. Albumin and heparin multilayer coatings for blood-contacting medical devices. Journal of Biomedical Material Researc., 2000, 51, pp. 249-257.

2. Edmondson R., Broglie J. J., Adcock A. F., Yang L. Three-Dimensional Cell Culture Systems and Their Applications in Drug Discovery and Cell-Based Biosensors. Assay Drug Dev. Technol., 2014, 1, 12 (4), pp. 207-218. DOI: 10.1089/adt.2014.573.

3. Ishizaki T, Saito N, Takai O. Correlation of cell adhesive behaviors on superhydrophobic, superhydrophilic, and micropatterned superhydrophobic/superhydrophilic surfaces to their surface chemistry. Langmuir. 2010, 26 (8), pp. 147-8154.

4. Keselowsky B. G., Collard D. M., Garcia A. J. Surface chemistry modulates focal adhesion composition and signals through changes in integrin binding. Biomaterials, 2004, 25, pp. 5947-5954.

5. Lakard S., Herlem G., Propper A., Kastner A., Michel G., Valle's-Villarreal N., Gharbi T., Fahys B. Adhesion and proliferation of cells on new polymers modified biomaterials. Bioelectrochemistr., 2004, 62, pp. 19-27.

6. Madich A., Sheremeta V., Hevkan I., Shtapenko O., Fedorova S., Slyvchuk Yu. Cell culture and its possible use in embryonic biotechnology. Manual for basic technique. Kyiv, ArtEkom, 2012, 144 p. (in Ukrainian)

7. Mathieu H. J. Bioengineered material surfaces for medical applications. Surf. Interface Anal., 2001, 32, pp. 3-9. DOI: 10.1002/sia.995.

8. Miksa D., Irish E. R., Chen D. Dextran functionalized surfaces via reductive amination: morphology, wetting, and adhesion. Biomacromolecules, 2006, vol. 7, pp. 557-564.

9. Noorisafa F., Razmjou A., Emams N., Low Z.-X., Korayem H., Kajani A. A. Surface modification of polyurethane via creating a biocompatible superhydrophilic nanostructured layer: role of surface chemistry and structure. Journal of Experimental Nanoscience, 2016, 11 (14), pp. 1087-1109.

10. O'Connor S. M., Andreadis J., Shaffer K. M., Ma W., Pancrazio J. J., Stenger D. A. Immobilization of neural cells in three-dimensional matrices for biosensor applications. Biosens. Bioelectron., 2000, 14, pp. 871-881.

11. Ohar M., Stetsyshyn Y., Kostruba A., Marintsova N., Zhurakhivska L., Fyodorova S., Shtapenko O., Novikov V. The formation and properties of a dextrancontaining coating for controlled adsorption of albumin and the growth of cells. Reports of the National Academy of Sciences of Ukraine, 2013, no. 5, pp. 511-517. (in Ukrainian)

12. Rabe M., Verdes D., Seeger S. Surface-induced spreading phenomenon of protein clusters. Soft Matter., 2009, vol. 5, pp. 1039-1047.

13. Shtapenko O., Gevkan I., Stetsyshyn Yu., Fedorova S., Sluvchyk Yu., Syrvatka V. The getting of functionalized nanolayers for the growth of cells, animals oocyte-cumulus complexes and embryos. Methodical recommendations. Lviv, 2015, 28 p. (in Ukrainian)

14. Thevenmot P., Hu W., Tang L. Surface chemistry influence implant biocompatibility. Cur. Top Med. Chem., 2008, 8 (4), pp. 270-280. 